\title{
Research Article: Effect of sturdy rice seedlings on the growth and yield of machine transplanted rice
}

\section{HEMALATHA AND M. JOSEPH}

Article Chronicle: Received :

11.07.2017;

Accepted :

24.07.2017

KEY WoRDS :

Sturdy rice seedling, Growth, Yield of machine transplanted rice 12. TECHSEAR(2)2017/459-464.
SUMMARY : Field experiments were conducted at Agricultural College and Research Institute, Killikulam, Tamil Nadu Agricultural University during Pishanam season of 2014-15 and 2015-16 to sustain the rice seedlings through different nutrient media and its influence on the growth and yield of machine transplanted rice. The experiments were laid out in Randomized Block Design (RBD) with three replications having ten treatments viz., Three nutrient media such as $70 \%$ soil $+20 \%$ well decomposed FYM + 10\% rice hull+Azospirillum @ $7 \mathrm{~g} /$ tray + DAP @ $7 \mathrm{~g} /$ tray, $70 \%$ soil + $20 \%$ well decomposed FYM + 10\% rice hull + DAP @ 7 g/tray +Vermicompost @ 100 g/tray + Azophos @ 14 g/tray, $70 \%$ soil + $20 \%$ well decomposed FYM + $10 \%$ rice hull + DAP @ $7 \mathrm{~g} /$ tray + Vermicompost @ $100 \mathrm{~g} /$ tray + Azophos @14 g/tray + Cycocel @100 ppm as seed treatment coupled with different seed rate of 20, 15 and $10 \mathrm{~kg} / \mathrm{ha}$ and it was compared with farmers practice of soil media using $20 \mathrm{~kg} / \mathrm{ha}$ of seed rate. Rice variety ADT (R) 45 was used as test crop. Media with $70 \%$ soil $+20 \%$ well decomposed FYM $+10 \%$ rice hull + DAP@ $7 \mathrm{~g} /$ tray + Vermicompost @ $100 \mathrm{~g} /$ tray +Azophos @ $14 \mathrm{~g} /$ tray with a seed rate of $20 \mathrm{~kg} /$ ha has produced the sturdy rice seedlings and produced the higher growth and yield of rice.

How to cite this article : Hemalatha, M. and Joseph, M. (2017). Effect of sturdy rice seedlings on the growth and yield of machine transplanted rice. Agric. Update, 12(TECHSEAR-2) : 459-464; DOI: 10.15740/HAS/AU/
Author for correspondence :

\section{HEMALATHA}

Department of

Agronomy, Agricultural

College and Research

Institute, KILLIKULAM

(T.N.) INDIA

Email:johems2004@

yahoo.co.in

See end of the article for

authors' affiliations 